\title{
ECLETICA
}

www.scielo.br/eq

Volume 31, número 3, 2006

\section{Sensitive bromatometric assay methods for finasteride in pharmaceuticals}

\author{
K. Basavaiah ${ }^{1 *}$, B.C. Somashekar ${ }^{l}$, U. R. Anilkumar ${ }^{l}$ and V. Ramakrishna ${ }^{2}$ \\ ${ }^{\prime}$ Department of chemistry, University of Mysore, Manasagangotri, Mysore-570 006, India \\ ${ }^{2}$ Department of Drugs Control in Karnataka, Govt. College of Pharmacy, Bangalore-560 027, India \\ *Corresponding author: E-mail: basavaiahk@yahoo.co.in
}

\begin{abstract}
Three sensitive spectrophotometric methods are presented for the determination of finasteride in bulk and in tablets. The methods rely on the use of bromate-bromide reagent and three dyes namely, methyl orange, indigocarmine and thymol blue as reagents. They involve the addition of a measured excess of bromate-bromide reagent to finasteride in acid medium, and after the bromination reaction is judged to be complete, the unreacted bromine is determined by reacting with a fixed amount of either methylorange and measuring the absorbance at $520 \mathrm{~nm}$ (method A) or indigocarmine and measuring the absorbance at $610 \mathrm{~nm}(\operatorname{method} \mathrm{B})$ or thymol blue and measuring the absorbance at 550 $\mathrm{nm}$ (method C). In all the methods, the amount of insitu generated bromine reacted corresponds to the amount of finasteride. The absorbance measured at the respective wavelength is found increase linearly with the concentration of finasteride. Beer's law is obeyed in the ranges 0.25- 2.0, 0.5-6.0 and 1-12 $\mu \mathrm{g} \mathrm{mL}-1$ for method $\mathrm{A}$, method $\mathrm{B}$ and method $\mathrm{C}$, respectively. The calculated molar absorptivity values are $5.7 \times 10^{4}, 3.12 \times 10^{4}$ and $1.77 \times 10^{4} \mathrm{~L} \mathrm{~mol}^{-1} \mathrm{~cm}^{-1}$ respectively, for method A, method $\mathrm{B}$ and method $\mathrm{C}$, and the corresponding Sandell sensitivity values are $0.0065,0.012$ and $0.021 \mu \mathrm{g} \mathrm{cm}^{-2}$. The limits of detection (LOD) and quantification (LOQ) are also reported for all the methods. Accuracy and, intraday and inter-day precisions of the methods were established according to the current ICH guidelines. The methods were successfully applied to the determination of finasteride in commercially available tablets and the results were found to closely agree with the label claim. The results of the methods were statistically compared with those of a reference method by applying Student's t-test and F-test. The accuracy and reliability of the methods were further confirmed by performing recovery tests via standard addition procedure.
\end{abstract}

Keywords: finasteride; spectrophotometry; bromate-bromide; dyes; tablets.

\section{Introduction}

Finasteride (FNS), chemically known as N(1,1-dimethylethyl) - 3- oxo- $(5 \alpha, 17 \beta)$-4-azaandrost- 1- ene-17- carboxamide (Fig 1)[1] is an antiandrogen which acts by inhibiting 5-alpha reductase, the enzyme that converts testosterone to dihydrotestosterone[2]. It is used in benign prosta- tic hyperplasia (BPH) in low doses and in prostate cancer in higher doses. Additionally, it is registered in many countries for male pattern-baldness. Many papers have been published on the determination of FNS in biological fluids[3], particularly in human plasma using high performance liquid chromatograph (HPLC)[4-11] with different detector systems. HPLC is the single most widely 
used technique for the determination of FNS in pure drug and related substances[12,13], tablets[14-16] and capsules[17]. HPLC has also been applied in stability indicating[18] and storage stability studies[19]. Ilango et al[20] have recently reported a UV-spectrophotometric method for the determination of FNS in tablet preparations and the method is reported to be applicable over 5-25 $\mu \mathrm{g} \mathrm{ml}-1$ concentration range. Other techniques including HPTLC[21], mid-infrared spectrophotometry[22] and polorography[23] devoted to assay in formulations are also found in the literature. The drug is official in Martindale, The Extra Pharmacopeia[24] and United States Pharmacopoeia[25] and the latter describes HPLC procedure for assay in pure drug and in tablets.

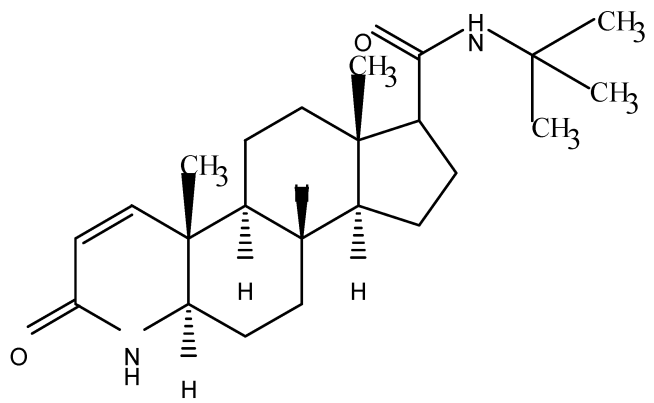

Figure 1. Structure of FNS.

Visible spectrophotometry, because of simplicity, sensitivity, reasonable accuracy and precision, and speed, has withstood the test of time and remained competitive with the newer analytical methods. There is only one report[26] on the visible spectrophotometric determination of FNS in pharmaceuticals and the method is based on the measurement of oxidative couple formed with 3methyl-2-benzothiazolinone hydrazone (MBTH) in the presence of iron(III) chloride, the colored product peaking at $446 \mathrm{~nm}$. Although the method is fairly sensitive (2- $\left.10 \mu \mathrm{g} \mathrm{mL}^{-1}\right)$, the chromogen formed is poorly stable, and the method employs an expensive reagent (MBTH). Further, of the reported HPLC methods, the method of Ziyang et al[12]. is quite sensitive with the detector response being linear in the concentration range 0.604-6.04 $\mu \mathrm{g} \mathrm{mL}-1$; all other methods lack the sensitivity expected of HPLC. In addition, the procedures require either derivatization of the compound or selective detectors and elaborate multi-step extractions. Added to this, the technique requires expensive instrumental set up and not accessible to many laboratories in developing and under developed countries. Even the polarographic methods are inadequately sensitive with the determination ranges being $8-40$ and 2-40 $\mu \mathrm{g} \mathrm{mL}^{-1}$ using direct current and differential pulse modes, respectively.

In previous papers, we have reported the successful use of bromate-bromide reagent and dyes such as methyl orange and indigocarmine for the sensitive spectrophotometric determination of a variety of pharmaceuticals[27-35]. The work communicated in this paper is aimed at developing sensitive and cost-effective spectrophotometric methods for the assay of FNS in pharmaceuticals. The methods make use of bromate-bromide mixture and are based on the bromination of the FNS molecule by insitu generated bromine and the latter's bleaching action on three dyes, viz; methyl orange, indigocarmine and thymol blue.

\section{Experimental}

\section{Apparatus}

A Systronics model 106 digital spectrophotometer with 1-cm matched quartz cells was used for all absorbance measurements.

\section{Reagents and Standards}

All chemicals used were of analytical purity grade and all solutions were prepared in distilled water.

Bromate-bromide mixture $(10,30$ and $60 \mu \mathrm{g}$ $\mathrm{mL}^{-1}$ in $\mathrm{KBrO}_{3}$ ). A stock standard solution equivalent to $1000 \mu \mathrm{g} \mathrm{mL}^{-1} \mathrm{KBrO}_{3}$ containing a large excess of $\mathrm{KBr}$ was first prepared by dissolving accurately weighed $100 \mathrm{mg}$ of $\mathrm{KBrO}_{3}$ and $1 \mathrm{~g}$ of $\mathrm{KBr}$ in water and diluting to the mark with water in a $100 \mathrm{~mL}$ calibrated flask. This was diluted stepwise to obtain working concentrations containing 10, 30 and $60 \mu \mathrm{g} \mathrm{mL}^{-1} \mathrm{KBrO}_{3}$ for use in method A, method B and method $\mathrm{C}$, respectively.

Hydrochloric acid. Concentrated hydrochloric acid (S.D. Fine Chem., Mumbai, India; sp. gr. 1.18) was diluted appropriately with 
water to get $5 \mathrm{~mol} \mathrm{~L}^{-1}$ for method $\mathrm{A}$ and method $\mathrm{C}$, and $2 \mathrm{~mol} \mathrm{~L}^{-1}$ for method B.

Methyl orange $\left(50 \mu g \mathrm{~mL}^{-1}\right)$. A $500 \mu \mathrm{g} \mathrm{mL}$ 1 dye solution was first prepared by dissolving accurately weighed $58.8 \mathrm{mg}$ of dye (S.D. Fine Chem., Mumbai, India, assay $85 \%$ ) in water and diluting to $100 \mathrm{~mL}$ in a calibrated flask and filtered using glass wool. It was diluted to obtain a working concentration of $50 \mu \mathrm{g} \mathrm{ml}^{-1}$.

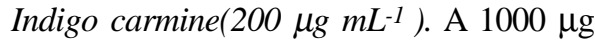
$\mathrm{mL}^{-1}$ stock standard solution was first prepared by dissolving accurately weighed $112 \mathrm{mg}$ of dye(S.D. Fine Chem., Mumbai, India, 90\% dye content) in water and diluting to volume in a $100 \mathrm{~mL}$ calibrated flask. The solution was then diluted 5-fold to get the working concentration of $200 \mu \mathrm{g} \mathrm{mL}-1$.

Thymo blue $\left(200 \mu \mathrm{g} \mathrm{mL}^{-1}\right)$. A $1000 \mu \mathrm{g} \mathrm{mL}$ ${ }^{1}$ stock standard solution was first prepared by dissolving accurately weighed $100 \mathrm{mg}$ of dye (Loba. Chemie, Mumbai, India, 100\% dye content) in water and diluting to volume in a 100 $\mathrm{ml}$ calibratd flask. The solution was then diluted 5 - fold to get the working concentration of $200 \mu \mathrm{g}$ $\mathrm{mL}^{-1}$.

Standard solution of finasteride. Pharmaceutical grade finasteride was received from Cipla Ltd, Bangalore, India, which was reported to be $99.8 \%$ pure, as gift, and was used as received. A stock standard solution equivalent to $1000 \mu \mathrm{g} \mathrm{mL}^{-1}$ FNS was prepared by dissolving accurately weighed amount of pure drug in $50 \mathrm{ml}$ of glacial acetic acid and diluting with water to a known volume. The same solution $\left(1000 \mu \mathrm{g} \mathrm{mL}^{-1}\right.$ FNS) was further diluted with water to get working concentrations of 5, 20 and $40 \mu \mathrm{g} \mathrm{mL}^{-1}$ for use in method A, method B, and method C, respectively. The standard solutions were kept in amber colored bottle and stored in a refrigerator when not in use.

\section{Procedures}

Method A. Different aliquots $(0.5,1.0,1.5$, $-4.0 \mathrm{~mL}$ ) of a standard $5 \mu \mathrm{g} \mathrm{mL}-1$ FNS solution were transferred into a series of $10 \mathrm{~mL}$ calibrated flasks by means of a micro burette and the total volume was adjusted to $4 \mathrm{~mL}$ by adding adequate quantity of water. To each flask were added $1 \mathrm{~mL}$ each of $5 \mathrm{~mol} \mathrm{~L}^{-1} \mathrm{HCl}$ and bromatebromide solution $\left(10 \mu \mathrm{g} \mathrm{mL}^{-1}\right.$ in $\left.\mathrm{KBrO}_{3}\right)$, the last being measured accurately. The flasks were stoppered, content mixed and let stand for $15 \mathrm{~min}$ with occasional shaking. Finally, $1 \mathrm{~mL}$ of $50 \mu \mathrm{g}$ $\mathrm{mL}^{-1}$ methyl orange solution was added (accurately measured) and the volume was diluted to the mark with water and mixed well. The absorbance of each solution was measured at 510 $\mathrm{nm}$ against a reagent blank after $5 \mathrm{~min}$.

Method B. Varying aliquots $(0.5,1.0$ $3.0 \mathrm{~mL}$ ) of a standard $20 \mu \mathrm{g} \mathrm{mL}^{-1}$ FNS solution were transferred into a series of $10 \mathrm{~mL}$ calibrated flasks by means of a micro burette and the total volume was brought to $3 \mathrm{~mL}$ by adding water. To each flask were added $2 \mathrm{~mL}$ of $2 \mathrm{~mol} \mathrm{~L}^{-1}$ hydrochloric acid and $1.5 \mathrm{~mL}$ of bromate-bromide solution $\left(30 \mu \mathrm{g} \mathrm{mL}^{-1}\right.$ in $\left.\mathrm{KBrO}_{3}\right)$ by means of a micro burette. The content was mixed well and the flasks were kept aside for 10 min with intermittent shaking. Finally, $1 \mathrm{~mL}$ of $200 \mu \mathrm{g} \mathrm{mL}-1$ indigo carmine solution was added to each flask, the volume was diluted to the mark with water, mixed well and absorbance measured against a reagent blank at $610 \mathrm{~nm}$ after $5 \mathrm{~min}$.

Method C. Different aliquots $(0.25,0.5$, $1.0,-3.0 \mathrm{~mL}$ ) of a standard $40 \mu \mathrm{g} \mathrm{mL}^{-1} \mathrm{FNS}$ solution were transferred into a series of $10 \mathrm{~mL}$ calibrated flasks by means of a micro burette and the total volume was adjusted to $3 \mathrm{~mL}$ by adding adequate quantity of water. To each flask were added $1 \mathrm{~mL}$ each of $5 \mathrm{~mol} \mathrm{~L}^{-1} \mathrm{HCl}$ and bromatebromide solution $\left(60 \mu \mathrm{g} \mathrm{mL}^{-1}\right.$ in $\left.\mathrm{KBrO}_{3}\right)$, the last being measured accurately. The flasks were stoppered, content mixed and let stand for $10 \mathrm{~min}$ with occasional shaking. Finally, $1 \mathrm{~mL}$ of $200 \mu \mathrm{g}$ $\mathrm{mL}^{-1}$ thymol blue solution was added (accurately measured) and the volume was diluted to the mark with water and mixed well. The absorbance of each solution was measured at $550 \mathrm{~nm}$ against a reagent blank after 5 min.

In either spectrophotometric method, a standard graph was prepared by plotting the absorbance versus the concentration of FNS. The concentration of the unknown was read from the calibration graph or computed from the regression equation derived using Beer's law data.

\section{Procedure for tablets}

Fifty tablets were accurately weighed and ground into a fine powder. A quantity of the 
powder equivalent to $100 \mathrm{mg}$ of FNS was accurately weighed into a $100 \mathrm{~mL}$ calibrated flask, $50 \mathrm{~mL}$ of glacial acetic acid added and shaken for $20 \mathrm{~min}$; the volume was finally diluted to the mark with water, mixed well and filtered using a Whatman No. 42 filter paper. The filtrate $\left(1000 \mu \mathrm{g} \mathrm{mL} \mathrm{mL}^{-1} \mathrm{FNS}\right)$ was appropriately diluted with water to get 5,20 and $40 \mu \mathrm{g} \mathrm{mL}^{-1} \mathrm{FNS}$ concentrations and analysed by spectrophotometric methods by taking convenient aliquots ( 1 or $2 \mathrm{~mL}$ ).

\section{Results and discussion}

\section{Method development}

The proposed spectrophotometric methods are indirect and are based on the determination of the residual bromine(insitu generated) after allowing the reaction between FNS and a measured amount of bromine to be complete. The bromine was determined by reacting it with a fixed amount of methyl orange, indigo carmine or thymol blue dye. The methods make use of bleaching action of bromine on the dyes, the decolouration being caused by the oxidative destruction of the dyes.

FNS, when added in increasing amounts to a fixed amount of insitu generated bromine, consumes the latter proportionally and there occurs a concomitant fall in the amount of bromine. When a fixed amount of dye is added to decreasing amounts of bromine, a concomitant increase in the concentration of dye results. Consequently, a proportional increase in the absorbance at the respective $\lambda_{\max }$ is observed with increasing concentration of FNS.

Preliminary experiments were performed to fix the upper concentrations of the dyes that could be determined spectrophotometrically, and these were found to be 5, 20 and $20 \mu \mathrm{g} \mathrm{mL-}$ ${ }^{1}$ for methyl orange, indigo carmine and thymol blue respectively. A bromate concentration of $1 \mu \mathrm{g} \mathrm{mL}^{-1}$ in the presence of excess of bromide was found to bleach the red colour due to $5 \mu \mathrm{g}$ $\mathrm{mL}^{-1}$ methyl orange whereas 4.5 and $6.0 \mu \mathrm{g} \mathrm{mL}$ 1 bromate was required to destroy the blue colour due to $20 \mu \mathrm{g} \mathrm{mL}^{-1}$ each of indigocarmine and thymol blue. Hence, different amounts of
FNS were reacted with $1 \mathrm{~mL}$ of $10 \mu \mathrm{g} \mathrm{mL}-1$ $\mathrm{KBrO}_{3}$ in method $\mathrm{A}, 1.5 \mathrm{~mL}$ of $30 \mu \mathrm{g} \mathrm{mL}^{-1}$ $\mathrm{KBrO}_{3}$ in method $\mathrm{B}$ and $1 \mathrm{~mL}$ of $60 \mu \mathrm{g} \mathrm{mL}-1$ $\mathrm{KBrO}_{3}$ in method $\mathrm{C}$ respectively, followed by determination of residual bromine as described under the respective procedure.

For both steps, i.e., the reaction between FNS and bromine, and the determination of the latter by reacting with the dye, $\mathrm{HCl}$ medium was found to be ideally suited. One $\mathrm{ml}$ of $5 \mathrm{~mol} \mathrm{~L}^{-1}$ acid in a total volume of about 5-7 mL was used for the method A and method C. Two $\mathrm{ml}$ of 2 $\mathrm{mol} \mathrm{L}^{-1}$ acid in a total volume of about $5 \mathrm{~mL}$ was used for the method B, and the same quantity of acid was maintained for the bleaching step. Reaction time of 10-15 min is not critical and any delay up to 20 min (method A and method B) and $30 \mathrm{~min}(\operatorname{method} \mathrm{C})$ did not affect the absorbance reading. A 5 min standing time was found necessary for the complete bleaching of the dye colour by the residual bromine. The absorbance of each dye colour was constant for several hours even in the presence of reaction product.

\section{Analytical data}

A linear correlation was found between absorbance at $\lambda_{\max }$ and concentration of FNS in the ranges given in Table 1. The graphs showed negligible intercept as described by the regression equation:

$$
\mathrm{Y}=\mathrm{a}+\mathrm{bX}
$$

(where $\mathrm{Y}=$ absorbance of 1-cm layer of solution; $\mathrm{a}=$ intercept; $\mathrm{b}=$ slope and $\mathrm{X}=$ concentration in $\mu \mathrm{g} \mathrm{mL}^{-1}$ ) . Regression analysis of the Beer's law data using the method of least squares was made to evaluate the slope(b), intercept(a) and correlation coefficient( $r$ ) for each system and the values are presented in Table 1. The optical characteristics such as Beer's law limits, molar absorptivity and Sandell sensitivity values of all the three methods are also given in Table 1 . The limits of detection(LOD) and quantitation(LOQ) calculated according to ICH guidelines[36] are also presented in Table 1 and reveal the very high sensitivity of the methods. 
Table 1. Analytical and regression parameters of spectrophotometric methods

\begin{tabular}{lccc}
\hline \multicolumn{1}{c}{ Parameter } & Method A & Method B & Method C \\
\hline$\lambda_{\max }, \mathrm{nm}$ & 510 & 610 & 550 \\
Beer's law limits, $\mu \mathrm{g} \mathrm{mL}^{-1}$ & $0.25-2.0$ & $0.5-6.0$ & $1-12$ \\
Molar absorptivity, $\mathrm{L} \mathrm{moL}^{-1} \mathrm{~cm}^{-1}$ & $5.69 \times 10^{4}$ & $3.12 \times 10^{4}$ & $1.77 \times 10^{4}$ \\
Sandell sensitivity, $\mu \mathrm{g} \mathrm{cm}^{-2}$ & 0.0065 & 0.0119 & 0.021 \\
Limit of detection, $\mu \mathrm{g} \mathrm{mL} \mathrm{m}^{-1}$ & 0.08 & 0.15 & 0.22 \\
Limit of quantification, $\mu \mathrm{g} \mathrm{mL} \mathrm{m}^{-1}$ & 0.23 & 0.45 & 0.67 \\
Regression equation, $\mathrm{Y}^{*}$ & & & \\
Intercept (a) & 0.0037 & 0.0109 & -0.0112 \\
Slope (b) & 0.1502 & 0.076 & 0.0511 \\
& & & \\
Correlation coefficient, (r) & & & \\
$\mathrm{S}_{\mathrm{a}}$ & 0.9998 & 0.9998 & 0.9999 \\
$\mathrm{~S}_{\mathrm{b}}$ & 0.0038 & 0.00285 & 0.0029 \\
\hline
\end{tabular}

$* \mathrm{Y}=\mathrm{a}+\mathrm{bX}$, where $\mathrm{Y}$ is the absorbance and $\mathrm{X}$ concentration in $\mu \mathrm{g} \mathrm{ml^{-1 }}$

$\mathrm{S}_{\mathrm{a}}$. Standard deviation of intercept.

$\mathrm{S}_{\mathrm{b}}$. Standard deviation of slope.

\section{Method Validation}

To evaluate the accuracy and intra-day precision of the methods, pure drug solution at three different levels (concentrations) was analysed, each determination being repeated seven times. The relative error $(\%)$ and relative standard deviation(\%) were less than 4.0 and indicate high accuracy and precision of the methods(Table 2). For a better pic- ture of reproducibility on a day-to-day basis, a series of experiments was performed in which standard drug solution at three different levels was determined each-day for five days with all solutions being prepared afresh each day. The day-to-day relative standard deviation values were in the range of $0.2-2.6 \%$ and represent the best appraisal of repeatability of the proposed methods.

Table 2. Intra-day Accuracy and precision of the methods

\begin{tabular}{|c|c|c|c|c|c|c|c|c|}
\hline Method & $\begin{array}{l}\text { FNS } \\
\text { taken, } \\
\mu \mathrm{g} \mathrm{ml}^{-1}\end{array}$ & $\begin{array}{l}\text { FNS } \\
\text { found, }{ }^{-1} \\
\mu \mathrm{g} \mathrm{ml}^{-1}\end{array}$ & $\begin{array}{l}\text { Range, } \\
\mu \mathrm{g} \mathrm{ml}^{-1}\end{array}$ & $\begin{array}{l}\text { Relative } \\
\text { error,\% }\end{array}$ & $\begin{array}{l}\mathrm{SD}, \\
\mu \mathrm{g} \mathrm{ml}^{-1}\end{array}$ & SEM & $\begin{array}{l}\text { RSD, } \\
\%\end{array}$ & $\begin{array}{l}\text { ROE, } \\
\%\end{array}$ \\
\hline \multirow[t]{3}{*}{ A } & 0.5 & 0.49 & 0.01 & 2.0 & 0.001 & 0.0004 & 0.24 & \pm 0.23 \\
\hline & 1.0 & 0.97 & 0.02 & 3.0 & 0.007 & 0.003 & 0.74 & \pm 0.73 \\
\hline & 1.5 & 1.48 & 0.06 & 1.3 & 0.019 & 0.007 & 1.28 & \pm 1.32 \\
\hline \multirow[t]{3}{*}{ B } & 1.0 & 1.05 & 0.08 & 3.0 & 0.027 & 0.0102 & 2.56 & \pm 2.55 \\
\hline & 3.0 & 2.94 & 0.07 & 2.0 & 0.036 & 0.0136 & 1.22 & \pm 1.21 \\
\hline & 5.0 & 4.96 & 0.09 & 0.8 & 0.032 & 0.0121 & 0.65 & \pm 0.64 \\
\hline \multirow[t]{3}{*}{$\mathrm{C}$} & 3.0 & 3.11 & 0.15 & 3.67 & 0.039 & 0.0147 & 1.25 & \pm 1.24 \\
\hline & 6.0 & 5.93 & 0.09 & 1.17 & 0.045 & 0.0170 & 0.76 & \pm 0.75 \\
\hline & 9.0 & 8.89 & 0.12 & 1.22 & 0.049 & 0.0185 & 0.55 & \pm 0.54 \\
\hline
\end{tabular}

*Mean value of seven determinations

SD. Standard deviation; SEM. Standard error of the mean.;

RSD. Relative standard deviation and ROE. Range of error at 95\% confidence

level for six degrees of freedom. 


\section{Application}

Four brands of FNS tablets in $5 \mathrm{mg}$ strength are currently available in the Indian market. The validity of the methods was checked by applying them to assay in three brands of tablets. Table 3 gives the results of assay and reveal that there is close agreement between the results obtained by the proposed methods and the label claim. The results were also compared statistically with those obtained by a reference method[20] by applying Student's t-test for accuracy and F-test for precision. The reference method consisted of the measurement of the absorbance of the drug solution in methanol at $206 \mathrm{~nm}$. At the $95 \%$ confidence level, the calculated t- and F-values did not exceed the tabulated values $(t=2.77$ and
$\mathrm{F}=6.39$ ) suggesting that the proposed methods are as accurate and precise as the reference method.

The accuracy and validity of the proposed methods were further ascertained by performing recovery experiments (Table 4). Preanalysed tablet powder was spiked with pure FNS at three different levels and the total was found by the proposed methods. Each determination was repeated three times. The recovery of pure drug added was quantitative(96.9-104.2\%) and revealed that coformulated substances such as talc, starch, gelatin, gum acacia, calcium carbonate, calcium gluconate, calcium dihydrogen orthophosphate, sodium alginate and magnesium stearate did not interfere in the determination.

Table 3. Results of assay of tablets by the proposed methods

\begin{tabular}{|c|c|c|c|c|c|}
\hline \multirow{2}{*}{$\begin{array}{c}\text { Dosage form } \\
\text { and brand } \\
\text { name* }\end{array}$} & \multirow{2}{*}{$\begin{array}{c}\text { Nomi } \\
\text { nal } \\
\text { amount, } \\
\text { mg per } \\
\text { tablet }\end{array}$} & \multirow{2}{*}{$\begin{array}{l}\text { Reference } \\
\text { method }\end{array}$} & \multirow[b]{2}{*}{ Method A } & \multirow{2}{*}{$\frac{\% \text { found }^{*} \pm \mathrm{SD}}{\text { Method B }}$} & \multirow[b]{2}{*}{ Method C } \\
\hline & & & & & \\
\hline \multicolumn{6}{|l|}{ Tablets } \\
\hline \multirow[t]{3}{*}{ FINCAR $^{\mathrm{a}}$} & 5 & $99.36 \pm 0.74$ & $100.36 \pm 0.86$ & $99.84 \pm 1.26$ & $101.7 \pm 1.55$ \\
\hline & & & $\mathrm{t}=1.98$ & $\mathrm{t}=0.76$ & $\mathrm{t}=3.23$ \\
\hline & & & $\mathrm{F}=1.35$ & $\mathrm{~F}=2.90$ & $\mathrm{~F}=4.38$ \\
\hline \multirow[t]{3}{*}{ FISTIDE $^{b}$} & 5 & $100.28 \pm 0.91$ & $98.67 \pm 1.16$ & $99.97 \pm 1.64$ & $101.34 \pm 1.45$ \\
\hline & & & $\mathrm{t}=2.46$ & $\mathrm{t}=0.38$ & $\mathrm{t}=1.42$ \\
\hline & & & $\mathrm{F}=1.62$ & $\mathrm{~F}=3.25$ & $\mathrm{~F}=2.53$ \\
\hline \multirow[t]{3}{*}{ FINAST $^{\mathrm{c}}$} & 5 & $102.6 \pm 1.54$ & $100.6 \pm 0.85$ & $99.5 \pm 1.30$ & $101.1 \pm 1.75$ \\
\hline & & & $t=2.64$ & $\mathrm{t}=3.45$ & $\mathrm{t}=1.44$ \\
\hline & & & $\mathrm{F}=3.28$ & $\mathrm{~F}=1.40$ & $\mathrm{~F}=1.29$ \\
\hline
\end{tabular}


Table 4. Results of recovery study

\begin{tabular}{llllll}
\hline Method & $\begin{array}{l}\text { Tablet } \\
\text { studied }\end{array}$ & $\begin{array}{l}\text { FNS } \\
\text { in } \\
\text { formulation, } \\
\boldsymbol{\mu g}\end{array}$ & $\begin{array}{l}\text { Pure } \\
\text { FNS } \\
\text { added, } \\
\boldsymbol{\mu g}\end{array}$ & $\begin{array}{l}\text { Total } \\
\text { found, } \\
\boldsymbol{\mu g}\end{array}$ & $\begin{array}{l}\text { Pure FNS } \\
\text { recovered, } \\
\mathbf{\%}\end{array}$ \\
\hline $\mathrm{A}$ & FINCAR & 5.02 & 3.0 & 8.14 & 104.2 \\
& $5 \mathrm{mg}$ & 5.02 & 6.0 & 11.19 & 103.0 \\
& & 5.02 & 12.0 & 17.21 & 101.6 \\
\hline $\mathrm{B}$ & & 19.97 & 10.0 & 29.74 & 97.7 \\
& & 19.97 & 20.0 & 39.93 & 99.8 \\
\hline $\mathrm{C}$ & 19.97 & 40.0 & 60.21 & 100.6 \\
& & 30.52 & 20.0 & 50.28 & 98.8 \\
& & 30.52 & 40.0 & 71.08 & 101.4 \\
\hline
\end{tabular}

**Mean value of three determinations

\section{Conclusions}

Three useful micro methods for the determination of FNS have been developed and validated as per the current ICH guidelines. The proposed methods are simple, rapid and costeffective. The methods are one of the most sensitive ever reported for finasteride and are superior to the existing HPLC and UVspecrophotmetric methods. They rely on the use of simple and cheap chemicals, and inexpensive techniques but provide a sensitivity comparable to that achieved by sophisticated and expensive technique like HPLC. These advantages coupled with good accuracy and precision make the methods highly suitable for routine use in laboratories as a part of industrial quality control.

\section{Acknowledgement}

The authors express their gratitude to Cipla Ltd, Bangalore, India. for supply of pure finasteride as gift. Three of the authors (BCS, URA and VRK,) thank the authorities of the University of Mysore, Mysore, for facilities. VRK is grateful to the Principal Secretary, Department of Health and Family Welfare, Govt of Karnataka, Bangalore, for permission.

Received 10 July 2006

Accepted 20 August 2006

\section{References}

[1] The Merck Index, $12^{\text {th }}$ Edn., Merck and Co. Inc, White House Station. N J, 691, (1994).

[2] Current Index of Medical Specialities (CIMS), Updated Prescriber's Hand Book, July-October 2005, PP.288, CMPMedia India Pvt. Ltd., Bangalore, India.

[3] G. Carlucci, P. Mazzeo, J. Chromatogr.-B: Biomed. Appl. 693 (1997) 245.

[4] B.K. Matuszewski, M.L. Constanzer, C.M. Chavez-Eng., Anal. Chem. 70 (1998) 882.

[5] T. Takano, S. Hata, J. Chromatogr. B: Biomed. Appl. 676 (1996) 141

[6] M.L. Constanzer, C.M. Chavez, B.K. Matuszewski, J. Chromatogr. B: Biomed. Appl. 658 (1994) 281.

[7] Yuquin, Y. Yang, L. Huichen, Yaowu Fenxi Zazhi 25 (2005) 30.

[8] X. Yuquing, L. Yanyan, Zhongguo Yaoke Daxue Xuebao 35 (2004) 187

[9] Zhiyong, C. Xiaoyan, Z.Yifan, Z. Dafang, Zhongguo Linchuang Yaolixue Zazhi 19 (2003) 196.

[10] L. Xiangyang, D, Li, L. Limin, Yaoxue Xuebao, 38 (2003) 445.

[11] P. Ptacek, J. Macek, J. Klima, J. Chromatogr, B: Biomed. Sci. Appl., 738 (2000) 305.

[12] L. Xiyang, C. Yifeng, C. Wansheng, Z. Bin, Z. Dong Liang, Yaowu Fenxi Zazhi, 23 (2003) 46.

[13] X. Mufeng, Zhongguo Yiyao Gongye Zazhi, 33 (2002) 341.

[14] M. F. Vitate, V.L. Perez, M. L. Palacios, M. T. Pizzorno, J. Liq. Chromatogr. Relat. Technol., 25 (2002) 3167.

[15] L. Xin-yuan, S. Yu-xin, Hebei Gongue Daxue Xuebao, 30 (2001) 66.

[16] D. Hulya, C. Aysen, S. Serap, Anal. Chimica Acta, 557(12) (2006) 252.

[17] Z. Li, L. Luosheng, L. Fengli, Yaowu Fenxi Zazhi, 22 (2002) 456.

[18] H. Rongfeng, F. Zhiying, W. Jian, S. Song, Zhongguo Yiyuan Yaoxue, 22 (2002) 287.

[19] A. A. Syed, M. K. Amshumali, J. Pharm. Biomed. Anal., 25 (2001) 1015

[20] K. Ilango, P. Valentina, K.S.Lakshmi, Indian Drugs, 40 (2003) 122. 
[21] S. N. Meyyanathan, G.V.S. Ramasarma, B. Suresh, J. Planar Chromatogr-Mod. TLC., 14 (2001) 188.

[22] J.A. Ryan, S.V. Compton, M.A. Brooks, D.A.C.Compton, J. Pharm. Biomed. Anal., 9 (1991) 303.

[23] S.M. Amer, Farmaco, 58 (2003) 159.

[24] Martindale, The Extrapharmacopoeia, 30 ${ }^{\text {th }}$ Edn; The pharmaceutical Press London. (1994) 691

[25] The United States of Pharmacopeia. United States

Pharamcopoeial Convention Inc., Rockville. 29 (2005) 907.

[26] K. Ilango, P. Valentina, K.S. Lakshmi; Indian J. Pharm.

Sci., 64, (2002). 174.

[27] K. Basavaiah, H.C. Prameela, Science Asia, 29 (2003)

147.

[28] K. Basavaiah, H.C. Prameela, Anal. Bioanal.Chem., 29 (2003) 25.
[29] K. Basavaiah, U. Chadrashekar, Acta Ciencia Indica Chem., 29 (2003) 25.

[30]. K. Basavaiah, P. Nagegowda, IL Farmaco, 59 (2004) 147. [31]. K. Basavaiah, P. Nagegowda, Oxid. Commun., 27 (2004) 203.

[32]. K. Basavaiah, H.C. Prameela, Indian J. Pharm. Sci., 67 (2004) 883.

[33]. K. Basavaiah, Indian J. Chem. Technol., 12 (2005) 149.

[34]. K. Basavaiah, P. Nagegowda, J. Braz. Chem. Soc., 16 (2005) 821.

[35]. K. Basavaiah, B.C. Somashekar, Indian J. Chem. Technol., 12 (2006) 316.

[36]. Text on Validation of Analytical Procedures, ICH Harmonized Tripartite Guideline,6. (1994). 